\title{
Effects of $\mathrm{PBr}_{3}$ Addition to Polysilane Thin Films on Structures and Photovoltaic Properties
}

\author{
Junya Nakagawa ${ }^{1}$, Takeo Oku ${ }^{1}$, Atsushi Suzuki ${ }^{1}$, Tsuyoshi Akiyama1, \\ Masahiro Yamada², Sakiko Fukunishi ${ }^{3}$, Kazufumi Kohno ${ }^{3}$ \\ ${ }^{1}$ Department of Materials Science, The University of Shiga Prefecture, Hikone, Japan \\ ${ }^{2}$ Osaka Gas Co., Ltd., Osaka, Japan \\ ${ }^{3}$ Osaka Gas Chemicals Co., Ltd., Osaka, Japan \\ Email:*oku@mat.usp.ac.jp
}

How to cite this paper: Nakagawa, J., Oku, T., Suzuki, A., Akiyama, T., Yamada, M., Fukunishi, S. and Kohno, K. (2017) Effects of $\mathrm{PBr}_{3}$ Addition to Polysilane Thin Films on Structures and Photovoltaic Properties. Green and Sustainable Chemistry, 7, 20-34. https://doi.org/10.4236/gsc.2017.71002

Received: December 22, 2016

Accepted: February 7, 2017

Published: February 10, 2017

Copyright $\odot 2017$ by authors and Scientific Research Publishing Inc. This work is licensed under the Creative Commons Attribution International License (CC BY 4.0).

http://creativecommons.org/licenses/by/4.0/

\begin{abstract}
Organic thin film solar cells are potential next generation solar cells. Many p-type semiconductors have been used in organic solar cells, but there have been far fewer reports involving n-type organic semiconductors. Developing new n-type organic semiconductors is therefore desirable. Polysilane thin films were spin-coated from solutions containing phosphorus $(\mathrm{P})$, and the effects of $\mathrm{P}$ addition on film microstructures and electronic properties as n-type semiconductors were investigated. Microstructures of poly-methyl-phenylsilane (PMPS), dimethyl-polysilane (DMPS) and deca-phenyl-penta-silane (DPPS) thin films were investigated by X-ray diffraction and transmission electron microscopy. PMPS thin films doped with P (PMPS(P)) were amorphous upon annealing at $300^{\circ} \mathrm{C}$, while DMPS(P) and DPPS(P) thin films exhibited crystalline structures. PMPS $(\mathrm{P})$ and DMPS(P) thin films exhibited decreased electrical resistances upon $P$ doping. The energy gaps of PMPS(P), DMPS(P) and DPPS(P) were 3.5, 3.9 and $3.8 \mathrm{eV}$, respectively. Decreased photoluminescence intensities of PMPS, DMPS and DPPS were observed upon P doping. The desorption of phenyl and methyl groups from PMPS(P) thin films was observed from Raman scattering measurements. Solar cells containing polysilane $(\mathrm{P}) /$ poly[3-hexylthiophene] heterojunction structures were fabricated and exhibited photovoltaic behavior.
\end{abstract}

\section{Keywords}

Microstructure, Thin Film, Property, Polysilane, Solar Cell

\section{Introduction}

Solar cells are a promising clean energy alternative to fossil fuels. The produc- 
tion cost of current silicon solar cells is high, and reducing the cost of solar cells is a priority. To this end, organic semiconductor based solar cell are potential next generation solar cells. Organic thin film solar cells are economical to produce, flexible and light weight, and their photovoltaic and optical properties have been much studied [1] [2] [3] [4]. Many p-type semiconductors have been used in organic solar cells, but there have been far fewer reports involving n-type organic semiconductors. Developing new n-type organic semiconductors is an important next step.

Polysilane materials are p-type semiconductors, and have been applied as conducting materials in photovoltaic systems [1]-[7]. Polysilanes are organic polymers containing main chain $\mathrm{Si}-\mathrm{Si}$ bonds and side chain organic substituents. They exhibit $\sigma$-conjugation along the Si main chain, and their hole mobility is ca. $10^{-4} \mathrm{~cm}^{2} \cdot \mathrm{V}^{-1} \cdot \mathrm{s}^{-1}$ [1]. Polysilane Si main chains are similar to $\sigma$-bonded polyolefin $\mathrm{C}$-C chains. Polysilanes possess a $3 \mathrm{p}$ orbital and an enlarged $\sigma$-orbital, compared with polyolefins with their $2 \mathrm{p}$ orbital. Polysilanes can potentially be applied as p-type semiconductors in organic thin film solar cells, but few studies on polysilane solar cells have been reported [1] [8] [9] [10]. Doped polysilanes can act as n-type semiconductors, and while they have been applied in organic solar cells, further investigation is needed [11] [12].

Herein, polysilane thin films were spin-coated from solutions of poly-methylphenyl-silane (PMPS), dimethyl-polysilane (DMPS) and deca-phenyl-penta-silane (DPPS) with phosphorus (P). The effect of $\mathrm{P}$ addition on film microstructures and electronic properties as n-type semiconductors were investigated. Spincoating is economical and applicable to the mass production of thin films. Light induced carrier separation and charge transfer was investigated from ultraviolet-visible (UV-vis) absorption and photoluminescence measurements. The effects of $\mathrm{P}$ addition were investigated from current density-voltage $(J-V)$ characteristics, UV-vis absorption and photoluminescence measurements and Raman scattering spectra [13] [14] [15]. Film microstructures were investigated by $\mathrm{X}$-ray diffraction (XRD) and transmission electron microscopy (TEM).

\section{Experimental Procedures}

Figure 1(a) shows the molecular structures of PMPS, DMPS, DPPS and phosphorus bromine $\left(\mathrm{PBr}_{3}\right)$ which was used as the $\mathrm{P}$ dopant. Indium tin oxide (ITO) glass plates (Xin Yan Technology, $\sim 10 \Omega / \square$ ) were ultrasonically cleaned with acetone and methanol, and dried under $\mathrm{N}_{2}$. Figure 1 (b) depicts a polysilane thin film deposited on a substrate. $\mathrm{PBr}_{3}(0.05 \mathrm{~mL}$, Wako) and PMPS or DPPS (24 mg, Osaka Gas Chemicals) or DMPS (24 mg, Strem Chemicals) were added to $1 \mathrm{~mL}$ of o-dichlorobenzene [8]. The resulting solution was spin-coated at $1000 \mathrm{rpm}$, and the substrate then annealed at $300^{\circ} \mathrm{C}$ for 10 min under $\mathrm{N}_{2}$. Au contacts were vacuum-evaporated as the top electrode.

The structure of solar cells is shown in Figure 1(c). ITO glass plates were cleaned as above. $\mathrm{TiO}_{\mathrm{x}}$ thin films were prepared by a sol-gel procedure, in which titanium tetraisopropoxide was mixed with 2-methoxyethanol and acetylacetone. 
(a)

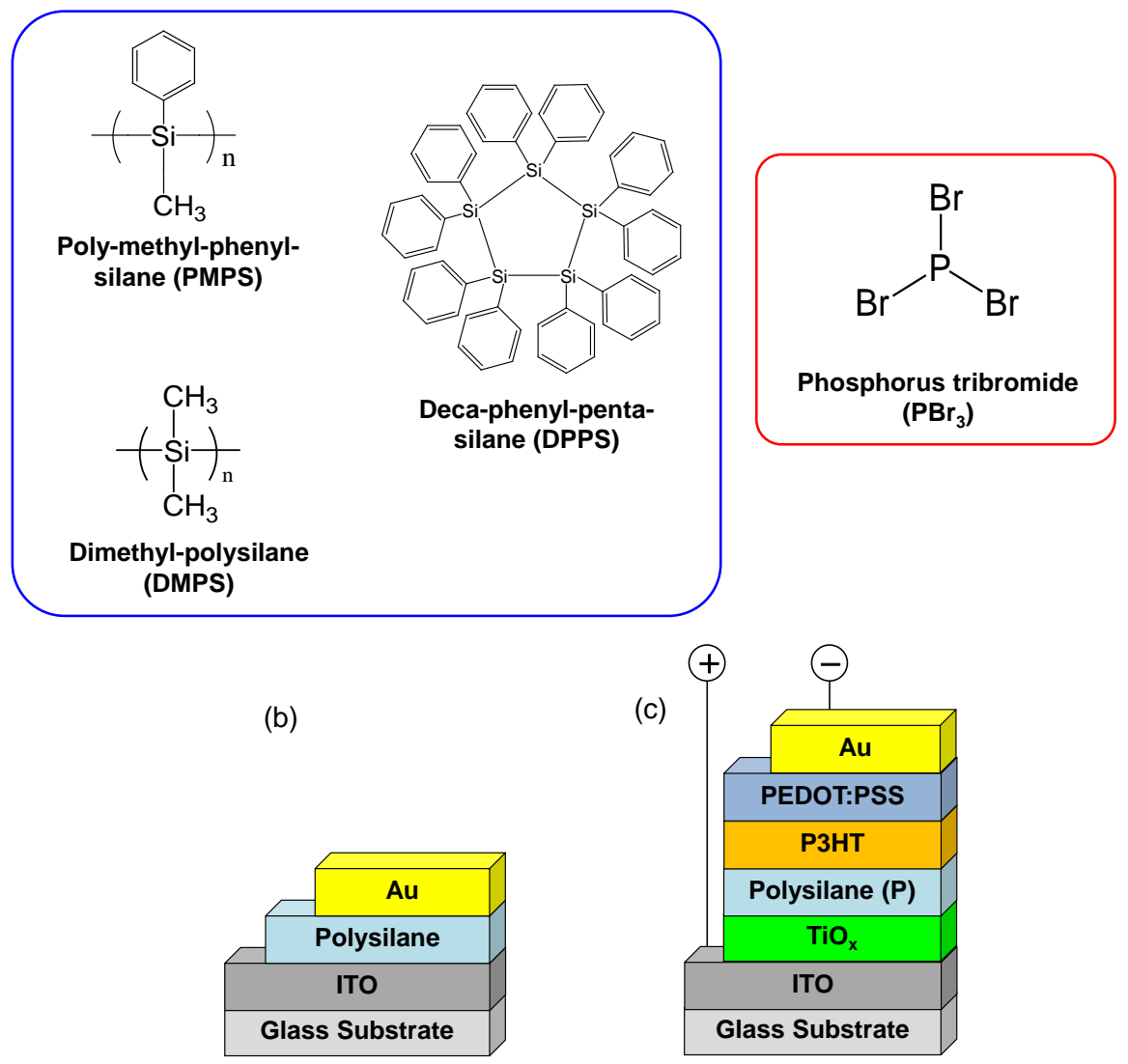

Figure 1. (a) Structures of PMPS, DMPS, DPPS and $\mathrm{PBr}_{3}$. (b) Structure of polysilane thin film deposited on substrate. (c) Structure of polysilane(P)/P3HT heterojunction solar cell.

The resulting $\mathrm{TiO}_{\mathrm{x}}$ precursor solution was spin-coated on the ITO substrate in air, and the substrate annealed at $140^{\circ} \mathrm{C}$ for $60 \mathrm{~min}$ in air. $\mathrm{PBr}_{3}(0.02 \mathrm{~mL})$ and polysilane $(24 \mathrm{mg})$ were added to $1 \mathrm{~mL}$ of o-dichlorobenzene, and the resulting solution spin-coated on the substrate at $1000 \mathrm{rpm}$.

The substrate was annealed at $300^{\circ} \mathrm{C}$ for $10 \mathrm{~min}$ in $\mathrm{N}_{2}$. Poly[3-hexylthiophene] (P3HT) (Sigma Aldrich) was spin-coated on the substrate at $1000 \mathrm{rpm}$, and the substrate annealed at $300^{\circ} \mathrm{C}$ for $10 \mathrm{~min}$ in air. Poly(3,4-ethylenedioxylenetthiophene): polystyrene sulfonic acid (PEDOT:PSS) was spin-coated on the substrate at $2000 \mathrm{rpm}$. Au contacts were vacuum-evaporated as the top electrode. The final device was annealed at $140^{\circ} \mathrm{C}$ for 10 min under $\mathrm{N}_{2}$.

Polysilane thin film microstructures were investigated by XRD (Philips, X'pert-MPD) with $\mathrm{CuK} \alpha$ radiation operated at $40 \mathrm{kV}$ and $40 \mathrm{~mA}$, and TEM (Hitachi, $\mathrm{H}-8100$ ) operated at $200 \mathrm{kV} . J-V$ characteristics were measured using a Hokuto Denko, HSV-110 apparatus in the dark, and using an AM 1.5 solar simulator (San-ei Electric, XES-301S).

Optical properties were investigated by UV-vis absorption spectroscopy (Jasco, V-670). Photoluminescence measurements were recorded using a Hitachi F-4500 spectrofluorometer. Film thicknesses were measured by atomic force microscopy (AFM; SII SPA400). Thin film carrier concentrations and mobilities were estimated using the Hall effect measurement system (Toyo, ResiTest 8320). 
Raman scattering spectra were recorded with a Raman laser spectrometer (Jasco, NRS-5100). Raman modes and optical images were observed using an excitation laser wavelength of $532 \mathrm{~nm}$.

\section{Results and Discussion}

\subsection{Microstructures of Thin Films}

XRD patterns of PMPS, DMPS and DPPS thin films after annealing are shown in Figure 2. PMPS did not exhibit sharp diffraction peaks, while DMPS and DPPS did. A broad peak at $2 \theta$ of $8.7^{\circ}$ was observed for PMPS, which disappeared upon addition of $\mathrm{PBr}_{3}$. The diffraction pattern of the P doped PMPS (PMPS(P)) thin film indicated the crystalline structure became amorphous upon doping.
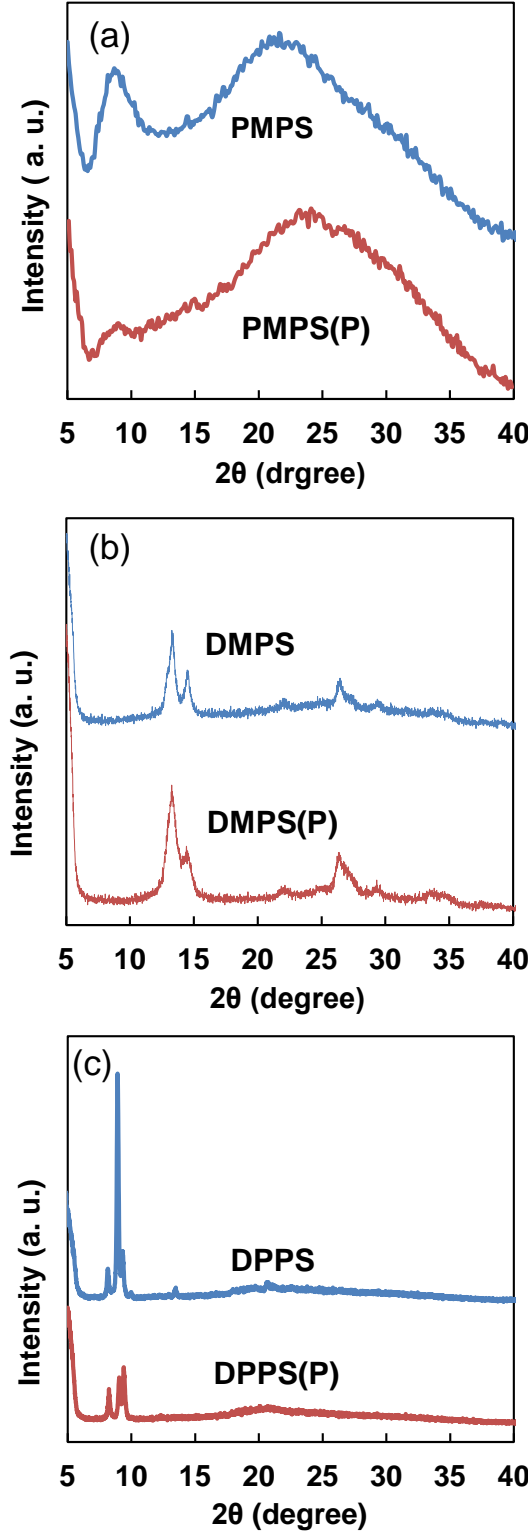

Figure 2. XRD patterns of annealed thin films of (a) PMPS, (b) DMPS and (c) DPPS thin films, with and without $\mathrm{P}$ doping. 
Diffraction peaks at $2 \theta$ of $13^{\circ}, 14^{\circ}$ and $26^{\circ}$ were observed for DMPS, and their intensity increased upon $\mathrm{P}$ doping. Diffraction peaks at $2 \theta$ of $8.2^{\circ}, 8.9^{\circ}, 9.4^{\circ}$ and $13^{\circ}$ were observed for DPPS, and their intensity decreased upon $\mathrm{P}$ doping. The XRD results indicate that DMPS and DPPS thin films were crystalline. Doping PMPS with P enhanced the decomposition of PMPS, facilitated the formation of the amorphous structure. The structure of DMPS contains less steric hindrance than that of PMPS, which accounts for the more crystalline nature of the DMPS thin film.

Crystallite sizes $(D)$ of PMPS(P), DMPS(P) and DPPS(P) thin films are summarized in Table 1. $D$ values were estimated from Scherrer's equation:

$$
D=0.9 \lambda / B \cos \theta
$$

where $\lambda, B$ and $\theta$ represent the X-ray source wavelength, full width at half maximum (FWHM) and Bragg angle, respectively. $D$ values of PMPS(P), DMPS(P) and DPPS(P) thin films were 6.9, 22 and $64 \mathrm{~nm}$, respectively.

Figure 3 shows TEM images of PMPS(P), DMPS(P) and DPPS(P) thin films,

Table 1. Structural parameters from XRD patterns of PMPS(P), DMPS(P) and DPPS(P) thin films.

\begin{tabular}{ccccc}
\hline Sample & $2 \theta\left(^{\circ}\right)$ & FWHM $2 \theta\left(^{\circ}\right)$ & $\mathrm{d}$ spacing $(\mathrm{nm})$ & $D(\mathrm{~nm})$ \\
\hline PMPS(P) & 8.670 & 2.3 & 10.19 & 6.9 \\
DMPS(P) & 13.25 & 0.73 & 6.677 & 22 \\
DPPS(P) & 8.859 & 0.25 & 9.982 & 64 \\
\hline
\end{tabular}
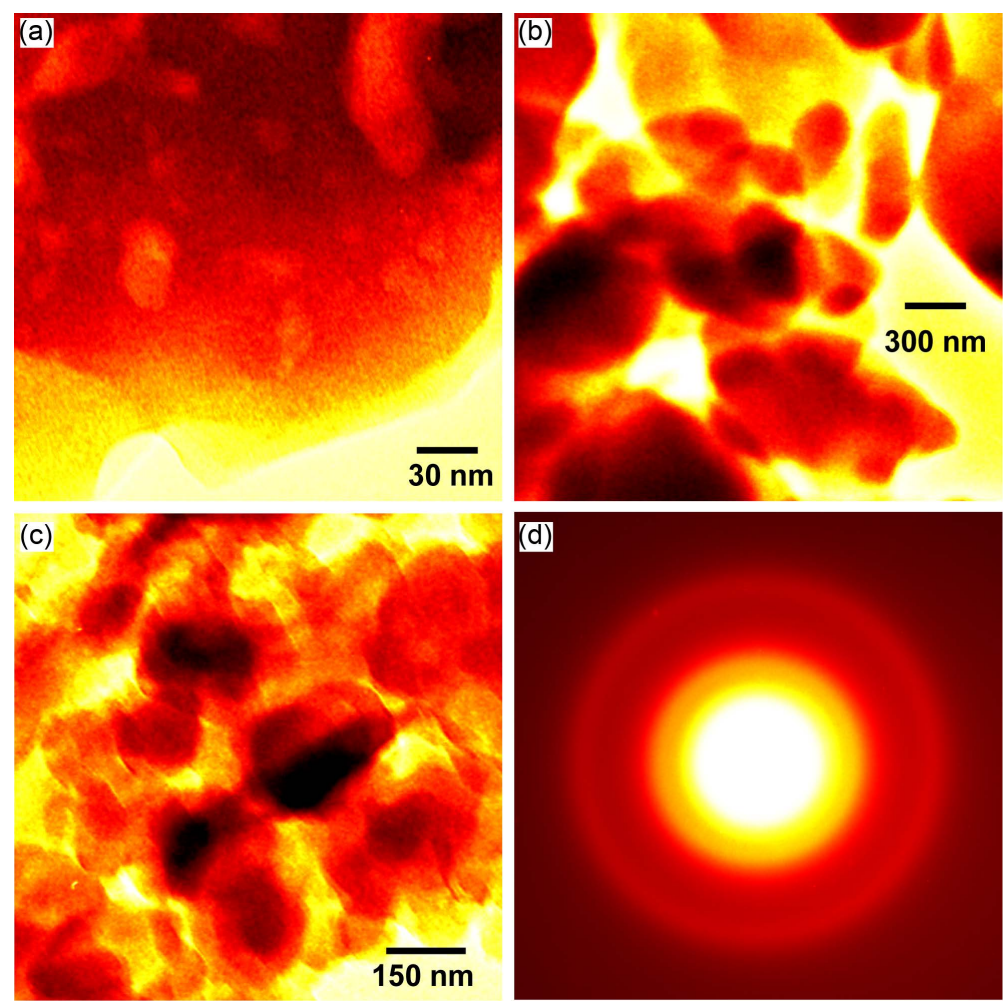

Figure 3. TEM images of (a) PMPS(P), (b) DMPS(P) and (c) DPPS(P) thin films, and (d) electron diffraction pattern of PMPS(P). 
and an electron diffraction pattern of PMPS(P). The polysilanes possessed nanoparticle structures, and the electron diffraction pattern of PMPS(P) indicated a relatively amorphous structure.

\subsection{Electronic and Optical Properties of Thin Films}

$J-V$ characteristics of polysilane thin films measured in the darkare shown in Figure 4. Table 2 shows electrical resistances of polysilane thin films calculated at +0.20 V. PMPS $(\mathrm{P})$ and DMPS(P) thin films exhibited decreased electrical resistances upon $\mathrm{P}$ doping. PMPS(P) exhibited n-type behavior, with a carrier
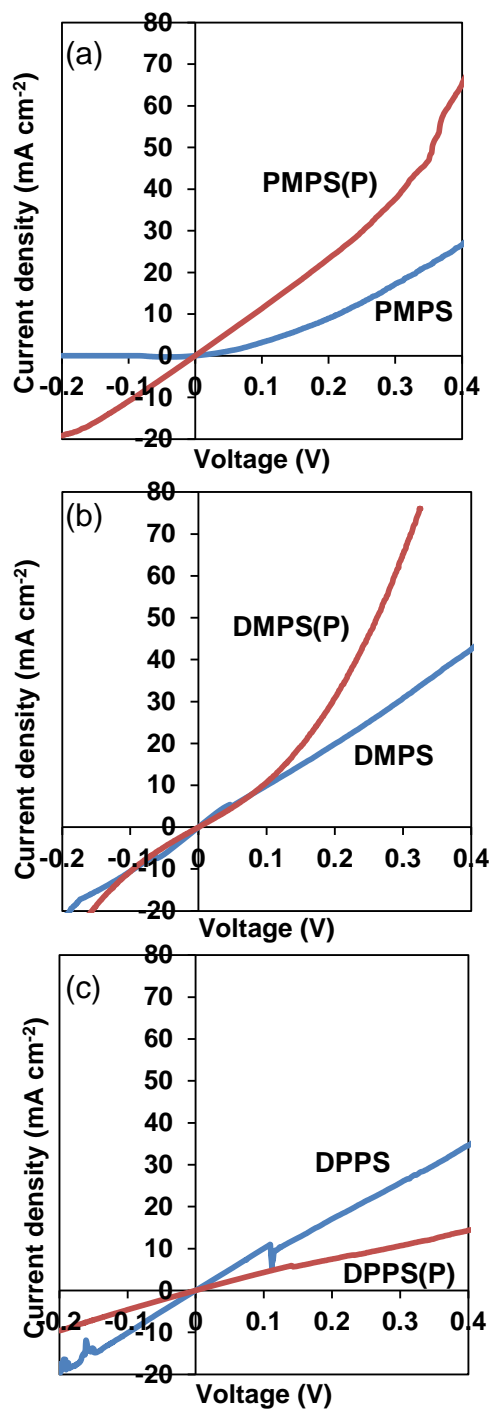

Figure 4. $J$ - $V$ characteristics of (a) PMPS, (b) DMPS and (c) DPPS thin films in the dark.

Table 2. Electrical resistances of undoped and P doped polysilane thin films.

\begin{tabular}{ccc}
\hline Sample & Resistance $\left(\Omega \mathrm{cm}^{2}\right)$ & Resistance $\left(\Omega \mathrm{cm}^{2}\right)$ after P doping \\
\hline PMPS & 20 & 10 \\
DMPS & 11 & 7.7 \\
DPPS & 12 & 33 \\
\hline
\end{tabular}


concentration and electron mobility of $1.0 \times 10^{19} \mathrm{~cm}^{-3}$ and $2.4 \mathrm{~cm}^{2} \cdot \mathrm{V}^{-1} \cdot \mathrm{s}^{-1}$, respectively.

Figure 5 shows UV-vis absorption spectra of PMPS, DMPS and DPPS thin films after annealing. All three exhibited obvious absorptions at $300-400 \mathrm{~nm}$, which increased in intensity upon doping. This suggests that increased photo absorption arose from the desorption of phenyl and methyl groups, from side chains in PMPS, DMPS and DPPS.

Transmittance spectra of PMPS, DMPS and DPPS thin films after annealing are shown in Figure 6. Film thicknesses were estimated to be $c a .1 \mu \mathrm{m}$ from AFM measurements. Tauc plots show $(\alpha h v)^{2}$ versus $h v$ values for PMPS, DMPS and DPPS thin films after annealing. Optical absorption coefficients $(\alpha)$ were determined from the spectral transmittance by:

$$
\alpha=1 / d \ln (1 / T),
$$
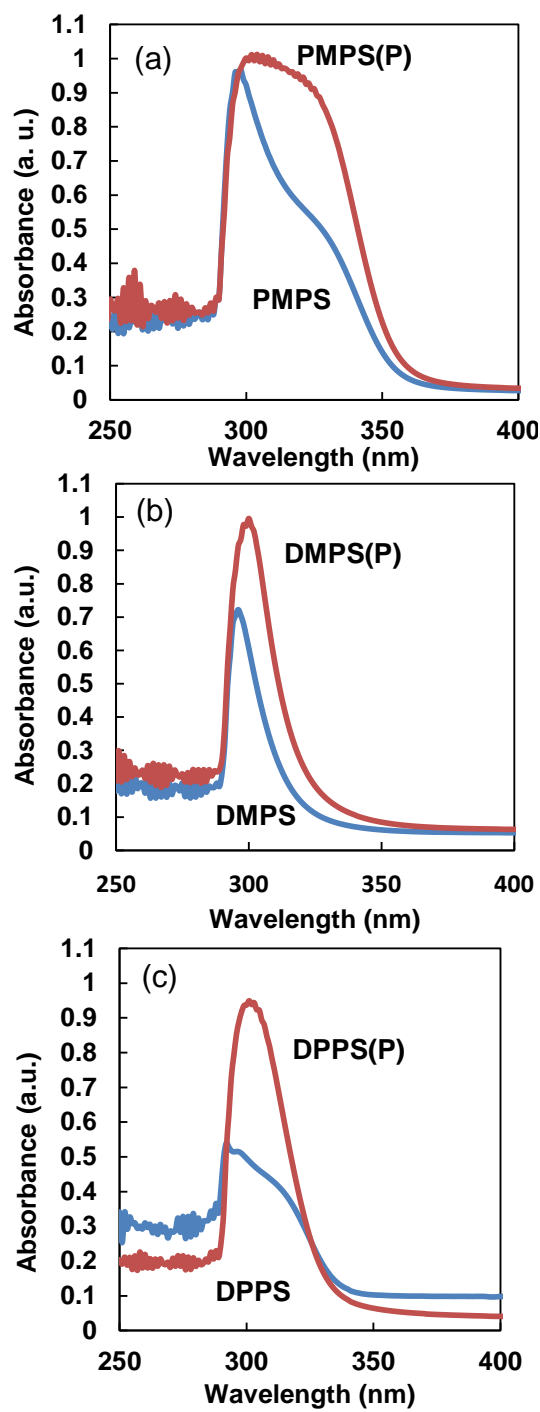

Figure 5. UV-vis absorption spectra of (a) PMPS, (b) DMPS and (c) DPPS thin films, with and without $\mathrm{P}$ doping. 
where $d$ and $T$ are the film thickness and transmittance, respectively [16]. Optical band gap energies $\left(E_{g}\right)$ were determined from:

$$
\alpha h v=A\left(h v-E_{g}\right) n / 2,
$$

where $h$ is Planck's constant, $v$ is the frequency and $n$ depends on the nature of the transition. $n$ was found to be 1 , corresponding to direct band to band transition. The intersection of the straight line with the $h v$ axis determines the value of $E_{g}$. Table 3 shows $E_{g}$ values of polysilane thin films with and without $\mathrm{P}$ doping.
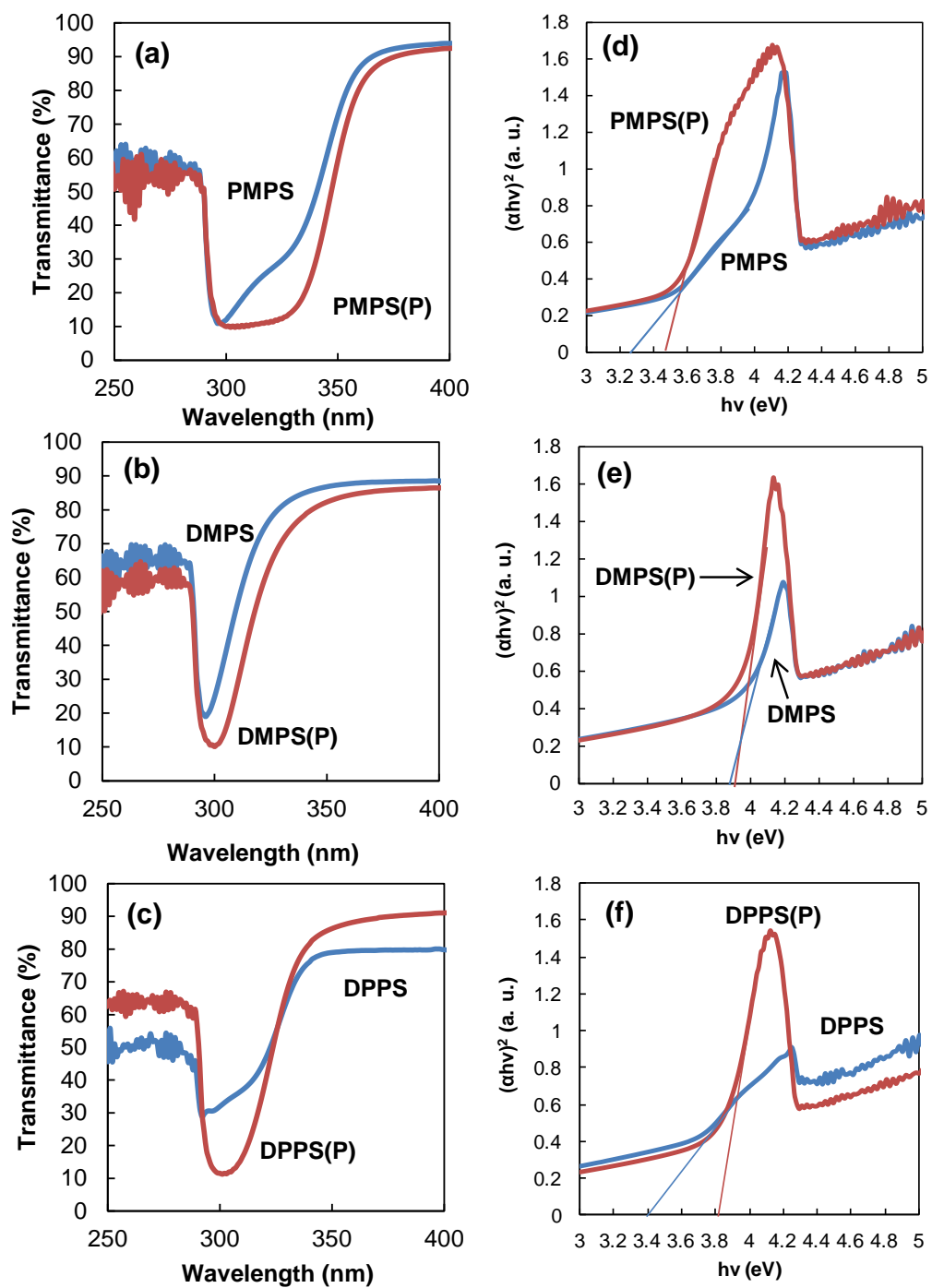

Figure 6. Optical transmission spectra of (a) PMPS, (b) DMPS and (c) DPPS thin films, with and without P doping. Tauc plots for (d) PMPS, (e) DMPS and (f) DPPS thin films with P doping.

Table 3. Energy gaps $\left(E_{g}\right)$ of undoped and $\mathrm{P}$ doped polysilane thin films.

\begin{tabular}{ccc}
\hline Sample & $E_{g}(\mathrm{eV})$ & $E_{g}(\mathrm{eV})$ after P doping \\
\hline PMPS & 3.3 & 3.5 \\
DMPS & 3.9 & 3.9 \\
DPPS & 3.4 & 3.8 \\
\hline
\end{tabular}


$E_{g}$ for PMPS, DMPS and DPPS were 3.3, 3.9 and $3.4 \mathrm{eV}$, respectively. $E_{g}$ for PMPS(P), DMPS(P) and DPPS(P) increased slightly to $3.5,3.9$ and $3.8 \mathrm{eV}$, respectively.

Photoluminescence spectra of PMPS, DMPS and DPPS thin films after annealing are shown in Figure 7. The excitation wavelength was $250 \mathrm{~nm}$. PMPS, DMPS and DPPS exhibited photoluminescence with emission at $300-450 \mathrm{~nm}$. Decreased photoluminescence intensities for PMPS, DMPS and DPPS were observed upon doping, attributed to structural transition from the addition of $\mathrm{PBr}_{3}$ and annealing at $300^{\circ} \mathrm{C}$. This characteristic has been previously explained by light-induced charge separation between polysilane units and P [17].

Raman scattering spectra of PMPS DMPS and DPPS thin films after annealing are shown in Figure 8. Raman active modes of the PMPS(P) film were observed at 1001,1032,1103, 1590, 2901, 2965 and $3053 \mathrm{~cm}^{-1}$. Peaks at 1001, 1032, 1103 and $1590 \mathrm{~cm}^{-1}$ in the spectrum of PMPS were attributed to phenyl group vibration modes. Peaks at 2901, 2965 and $3053 \mathrm{~cm}^{-1}$ in the spectrum of PMPS were attributed to methyl group vibration modes. Adding $\mathrm{PBr}_{3}$ to PMPS decreased the
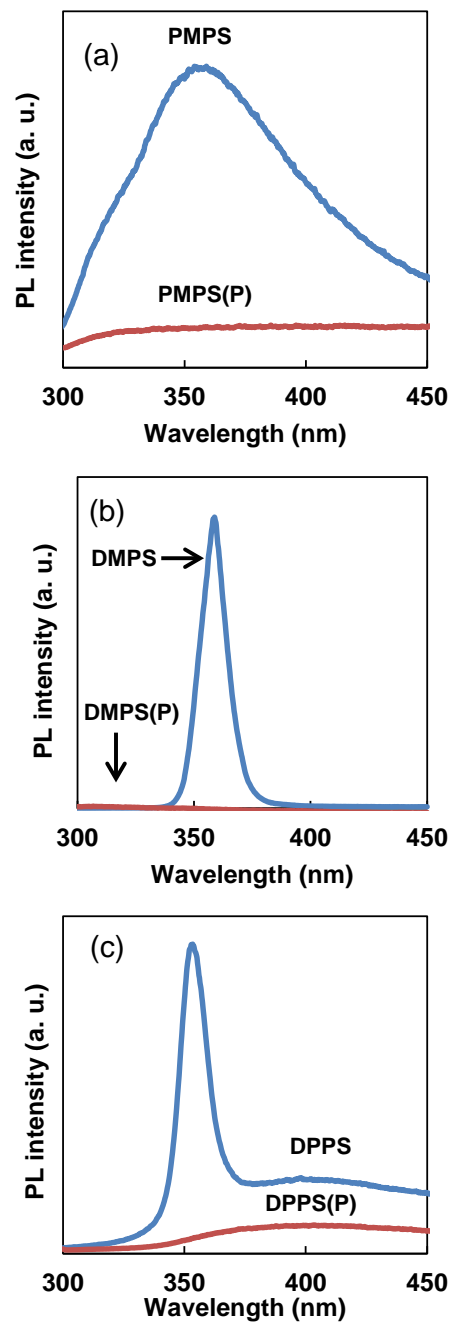

Figure 7. Photoluminescence spectra of (a) PMPS, (b) DMPS and (c) DPPS thin films, with and without $\mathrm{P}$ doping. 

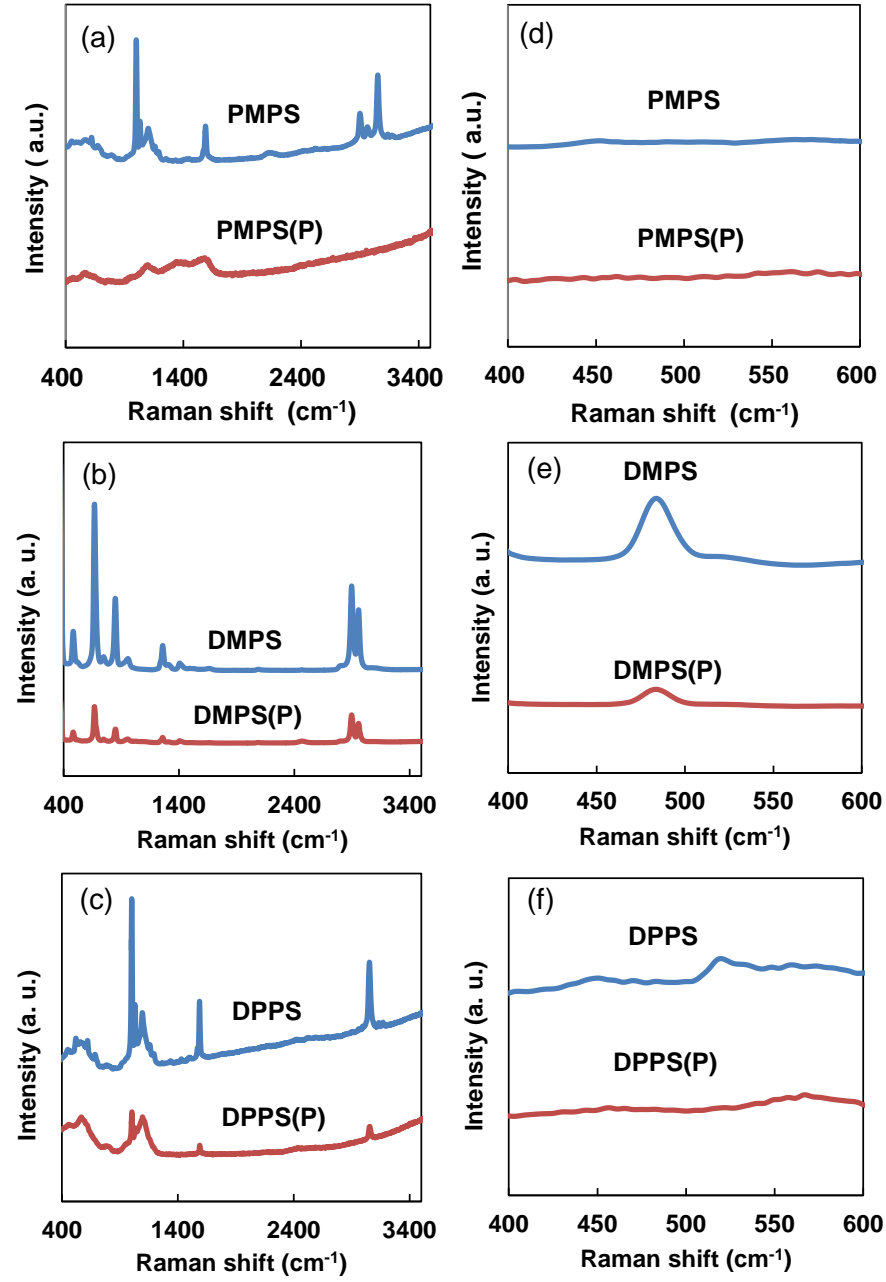

Figure 8. Raman scattering spectra of (a) and (d) PMPS, (b) and (e) DMPS and (c) and (f) DPPS thin films, with and without P doping.

peaks at 1001, 1590, 2901, 2965 and $3053 \mathrm{~cm}^{-1}$. Vibrations of the Si crystal lattice at ca. $520 \mathrm{~cm}^{-1}$ [18] were not observed in the spectra of the PMPS or PMPS(P) thin films. A peak at $480 \mathrm{~cm}^{-1}$ was observed in the spectrum of the DMPS thin film owing to amorphous $\mathrm{Si}$ [8], and its intensity decreased upon doping. No peaks were apparent at $400-600 \mathrm{~cm}^{-1}$ in the spectrum of the DPPS thin film.

Proposed mechanisms for P doping in PMPS, DMPS and DPPS are shown in Figure 9. Phenyl and methyl groups in PMPS side chains desorbed during annealing at $300^{\circ} \mathrm{C}$, and $-\mathrm{PBr}_{2}$ bound to PMPS side chains. Methyl bromide and benzene bromide were formed, and an amorphous structure formed from the $\mathrm{Si}$ chain structure [19]. Numerous methyl groups desorbed from DMPS side chains, and $-\mathrm{PBr}_{2}$ bound to side chains during annealing. Methyl bromide was formed, and an amorphous structure was formed from the main Si chain structure. A Si ring opening reaction occurred in DPPS. Si-Si bonds were broken, and numerous phenyl groups also desorbed from DPPS side chains.

\subsection{Photovoltaic Properties of Thin Films}

Parameters measured for PMPS(P)/P3HT, DMPS(P)/P3HT and DPPS(P)/P3HT 
(a)

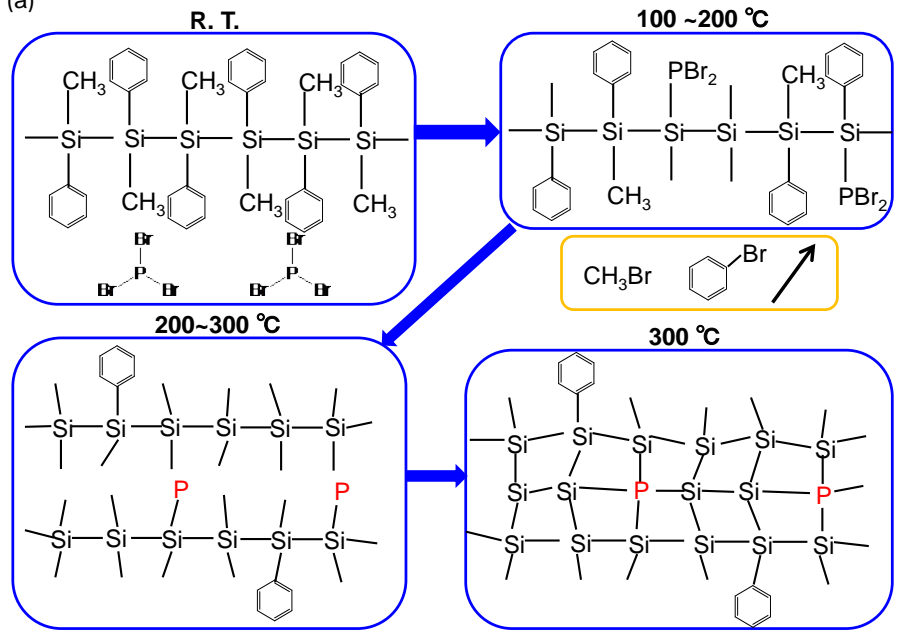

(b)

R. T.

$100 \sim 200{ }^{\circ} \mathrm{C}$

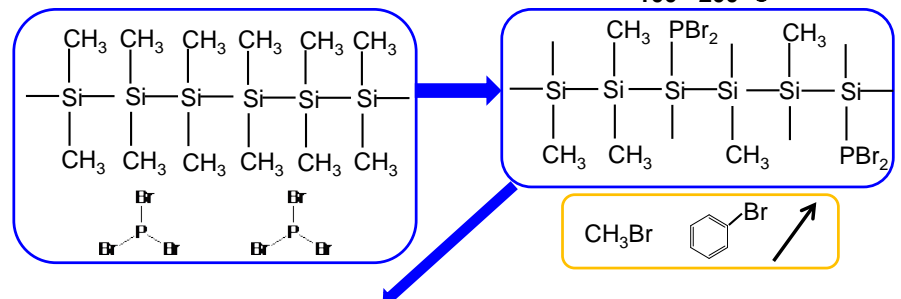

$200 \sim 300{ }^{\circ} \mathrm{C}$

$300{ }^{\circ} \mathrm{C}$
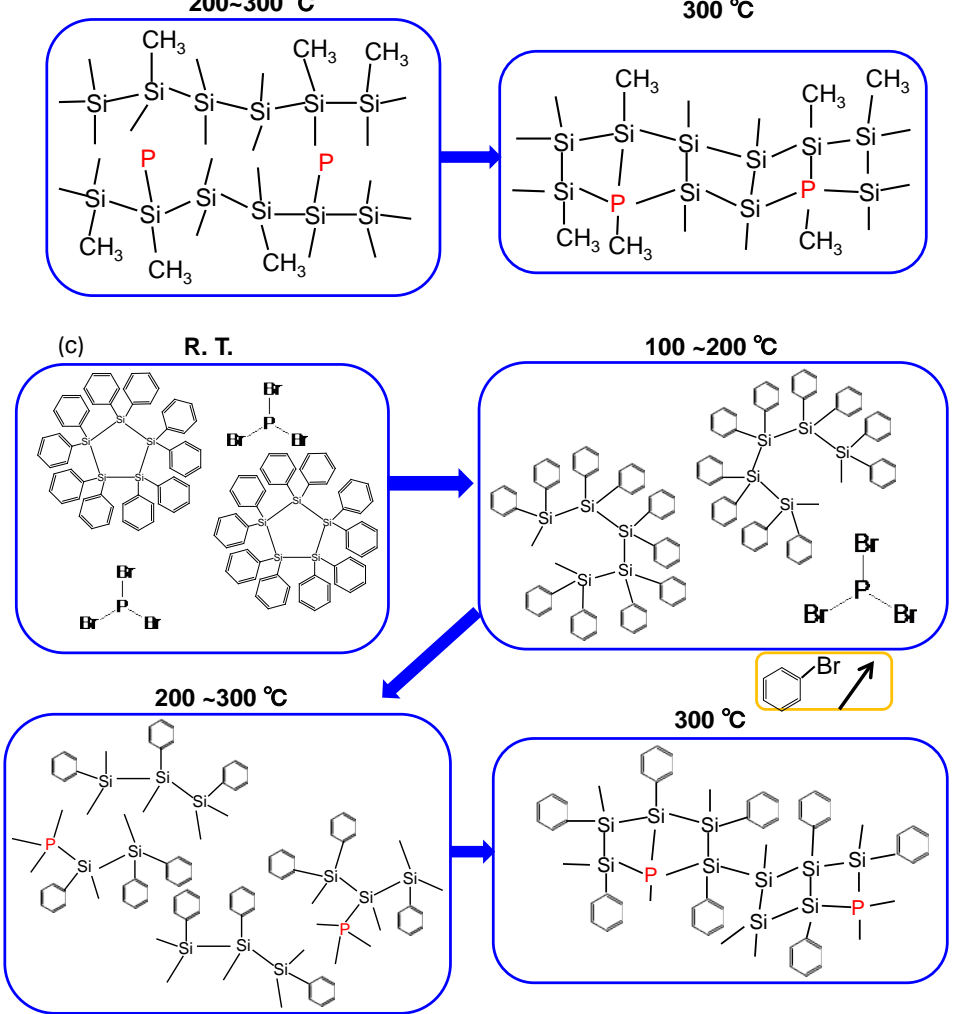

Figure 9. Proposed changes in microstructure of (a) PMPS(P), (b) DMPS(P) and (c) DPPS(P) during annealing.

heterojunction solar cells are summarized in Table 4. The ITO/TiO $/ \mathrm{PMPS}(\mathrm{P}) /$ P3HT/PEDOT:PSS/Au solar cell generated a photocurrent and photovoltage, 
with an open-circuit voltage $\left(V_{O C}\right)$ of $0.14 \mathrm{~V}$, short-circuit current $\left(J_{S C}\right)$ of 0.049 $\mathrm{mA} \cdot \mathrm{cm}^{-2}$, fill factor $(F F)$ of 0.21 and power conversion efficiency $(\eta)$ of $1.9 \times$ $10^{-3} \%$. These parameters were better than those exhibited by the other devices, as shown in Figure 10. The photoresponse arose from photoinduced carriers generated at P3HT layers. $\eta$ is lower than values of ordinary organic solar cells, which is attributed to interfacial defects of the p-n junction. Further improvement of the interfacial structure is therefore necessary.

The energy level diagram of the PMPS(P)/P3HT heterojunction solar cell is shown in Figure 11, in which reported values were used for energy levels [20] [21]. P3HT generated the electronic carriers in the PMPS(P)/P3HT heterojunction solar cell, which explained the increase in efficiency.

Table 4. Photovoltaic parameters of polysilane(P)/P3HT heterojunction solar cells.

\begin{tabular}{ccccc}
\hline Sample & $J_{S C}\left(\mathrm{~mA} \cdot \mathrm{cm}^{-2}\right)$ & $V_{O C}(\mathrm{~V})$ & $F F$ & $\eta(\%)$ \\
\hline PMPS(P)/P3HT & 0.049 & 0.14 & 0.28 & $1.9 \times 10^{-3}$ \\
DMPS(P)/P3HT & 0.020 & 0.096 & 0.34 & $6.6 \times 10^{-4}$ \\
DPPS(P)/P3HT & 0.053 & 0.10 & 0.27 & $1.4 \times 10^{-3}$ \\
\hline
\end{tabular}

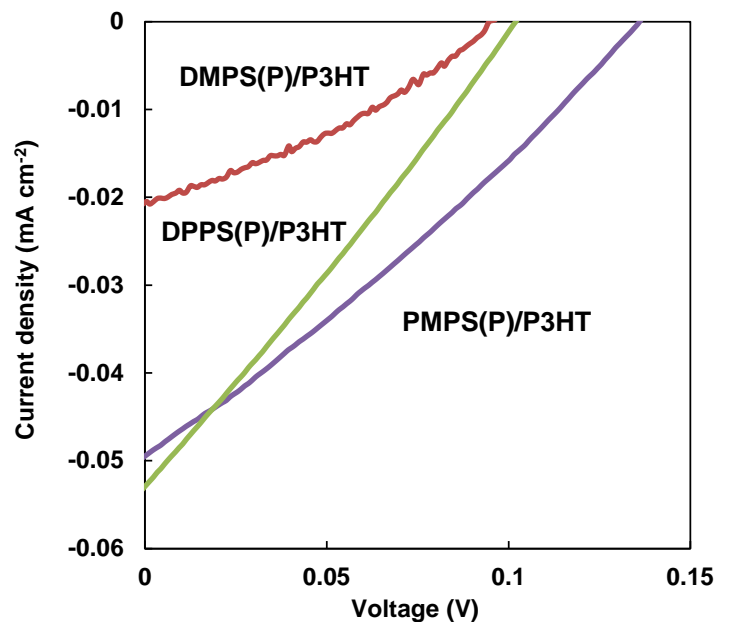

Figure 10. $J-V$ characteristics of $\mathrm{PMPS}(\mathrm{P}) / \mathrm{P} 3 \mathrm{HT}$, DMPS(P)/P3HT and DPPS(P)/P3HT heterojunction solar cells under AM1.5 solar simulation.

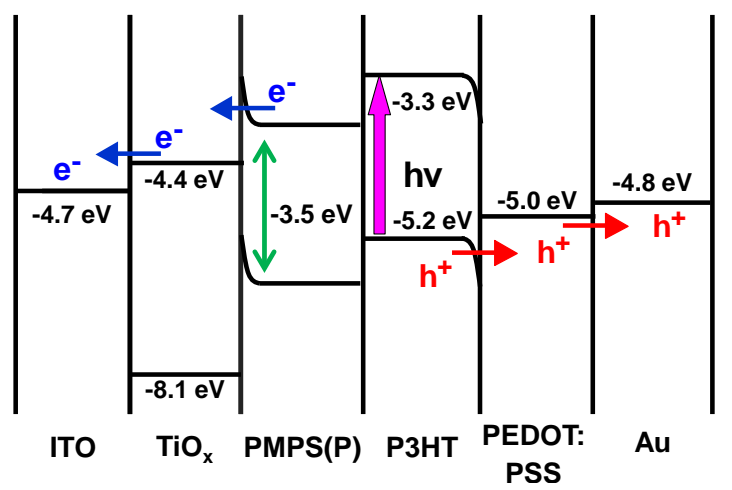

Figure 11. Energy level diagram of the PMPS(P)/P3HT heterojunction solar cell. 
Energy barriers existed near the semiconductor/metal interface, and charge was transferred by light irradiation from the ITO substrate side. Holes were transported to the Au electrode and electrons to the ITO substrate. The present polysilane materials might also be utilized as hole transport materials for the recent developed perovskite - based solar cells [22] [23].

\section{Conclusion}

PMPS, DMPS and DPPS thin films were fabricated by spin-coating, and the effect of doping with $\mathrm{P}$ was investigated. PMPS(P) thin films exhibited an amorphous structure after annealing at $300^{\circ} \mathrm{C}$, while DMPS(P) and DPPS(P) thin films were crystalline after annealing. Crystallite sizes of PMPS(P), DMPS(P) and DPPS(P) thin films were 6.9, 22 and $64 \mathrm{~nm}$, respectively, and the polysilane films possessed nanoparticle structures. In the absence of light, PMPS(P) and DMPS(P) thin films exhibited decreased electrical resistances upon $\mathrm{P}$ doping. The energy gaps of PMPS, DMPS and DPPS were 3.3, 3.9 and $3.4 \mathrm{eV}$, respectively, and those of PMPS(P), DMPS(P) and DPPS(P) were 3.5, 3.9 and $3.8 \mathrm{eV}$, respectively. A decrease in photoluminescence intensity of all thin films was observed upon $\mathrm{P}$ doping, because of light-induced charge separation between polysilane units and $\mathrm{P}$. Annealing at $300^{\circ} \mathrm{C}$ caused the desorption of phenyl and methyl groups from PMPS(P) side chains. A peak at $480 \mathrm{~cm}^{-1}$ was observed in the Raman spectrum of the DMPS thin film. This arose from amorphous $\mathrm{Si}$, and decreased in intensity upon $\mathrm{P}$ doping. Thus, $\mathrm{P}$ was doped in polysilanes, and PMPS acted as an n-type semiconductor. Solar cells with PMPS(P)/P3HT, DMPS(P)/ P3HT and DPPS(P)/P3HT heterojunction structures were fabricated and exhibited photovoltaic behavior.

\section{Acknowledgements}

This work was partly supported by Satellite Cluster Program of the Japan Science and Technology Agency, and a Grant-in-Aid for Scientific Research (C) No. 25420760 .

\section{References}

[1] Lee, J., Seoul, C., Park, J. and York, J. (2004) Fullerene/poly(methylphenylsilane) (PMPS) Organic Photovoltaic Cells. Synthetic Metals, 145, 11-14. https://doi.org/10.1016/j.synthmet.2004.04.022

[2] Silence, S., Scott, J., Hache, F., Ginsbrug, E., Jenkner, P., Miller, P., Twieg, R. and Moermer, W. (1993) Poly(silane)-Based High-Mobility Photorefractive Polymers. Journal of the Optical Society of America B, 10, 2306-2312. https://doi.org/10.1364/josab.10.002306

[3] Jung, J., Ciesielski, W. and Ulanski, J. (2006) Photovoltaic Effect in Novel Polysilane with Phenothiazine Rings and Its Blends with Fullerene. Materials Science-Poland, 24, 527-534.

[4] Masuda, T., Matsuki, Y. and Simoda, T. (2012) Stability of Polydihydrosilane Liquid Films on Solid Substrates. Thin Solid Films, 520, 5091-5096. https://doi.org/10.1016/j.tsf.2012.03.043 
[5] Masuda, T., Matsuki, Y. and Simoda, T. (2012) Pyrolytic Transformation from Polydihydrosilane to Hydrogenated Amorphous Silicon Film. Thin Solid Films, 520, 6603-6607. https://doi.org/10.1016/j.tsf.2012.07.028

[6] Masuda, T., Matsuki, Y. and Simoda, T. (2009) Spectral Parameters and hamaker Constants of Silicon Hydride Compounds and Organic Solvents. Journal of Colloid and Interface Science, 340, 298-305. https://doi.org/10.1016/j.jcis.2009.08.028

[7] Iyer, G.R.S., Hobbie, E.K., Guruvenket, S., Hoey, J.M., Anderson, K.J., Lovaasen, J., Gette, C., Schulz, D.L., Swenson, O.F., Elangovan, A. and Boudjouk, P. (2012) Solution-Based Synthesis of Crystalline Silicon from Liquid Silane through Laser and Chemical Annealing. Applied Materials and Interfaces, 4, 2680-2685.

https://doi.org/10.1021/am300334p

[8] Shimoda, T., Matsuki, Y., Furusawa, M., Aoki, T., Yudasaka, I., Tanaka, H., Iwasaki, H., Wang, D., Miyasaka, M. and Takeuchi, Y. (2006) Solution-Processed Silicon Films and Transistors. Nature, 440, 783-786. https://doi.org/10.1038/nature04613

[9] Nakagawa, J., Oku, T., Suzuki, A., Akiyama, T., Tokumitsu, K., Yamada, M. and Nakamura, N. (2012) Fabrication and Characterization of Polysilane/C 60 Thin Film Solar Cells. Journal of Physics Conference Series, 352, 012019-1-5. https://doi.org/10.1088/1742-6596/352/1/012019

[10] Kawashima, A., Oku, T., Suzuki, A., Kikuchi, K. and Kikuchi, S. (2012) Microstructures and Photovoltaic Properties of Polysilane/C60-Based Solar Cells. Materials Science and Applications, 3, 557-561. https://doi.org/10.4236/msa.2012.38079

[11] Masuda, T., Sotani, N., Hamada, H., Matsuki, Y. and Simoda, T. (2012) Fabrication of Solution-Processed Hydrogenated Amorphous Silicon Single-Junction Solar Cells. Applied Physics Letters, 100, Article ID: 253908. https://doi.org/10.1063/1.4730614

[12] Oku, T., Nakagawa, J., Iwase, M., Kawashima, A., Yoshida, K., Suzuki, A., Akiyama, T., Tokumitsu, K., Yamada, M. and Nakamura, M. (2013) Microstructures and Photovoltaic Properties of Polysilane-Based Solar Cells. Japanese Journal of Applied Physics, 52, Article ID: 04CR07. https://doi.org/10.7567/jiap.52.04cr07

[13] Martin, P.H., Irmer, G. and Muller, E. (1998) Submicro Structure of Silicon Carbide Derived from Poly(Methylchlorosilane). Journal of the European Ceramic Society, 18, 193-199. https://doi.org/10.1016/S0955-2219(97)00125-8

[14] Boo, B.H. (2011) Infrared and Raman Spectroscopic Studies Tris (Trimethylsilyl) Silanederivatives of $\left.\left(\mathrm{CF}_{3}\right)(3) \mathrm{Si}\right)(3) \mathrm{Si}-\mathrm{X}\left[\mathrm{X}=\mathrm{H}, \mathrm{Cl}, \mathrm{OH}, \mathrm{CH}_{3}, \mathrm{OCH}_{3}, \mathrm{Si}\left(\mathrm{CH}_{3}\right)(3)\right]$ : Vibrational Assignments by Hartree-Fock and Density-Functional Theory Calculations. Journal of the Korean Physical Society, 59, 3192-3200.

[15] Boo, B.H. (2011) Infrared and Ramanspectroscopy of Diphenylsilane. Vibrational Assignment by Hartree-Fock and Density-Functional Theory Calculations. Journal of the Korean Physical Society, 59, 3205-3209. https://doi.org/10.3938/jkps.59.3205

[16] Kidowaki, H., Oku, T. and Akiyama, T. (2012) Fabrication and Evaluation of $\mathrm{CuO} / \mathrm{ZnO}$ Heterostructures for Photoelectric Conversion. International Journal of Research and Reviews in Applied Sciences, 13, 67-72.

[17] Tanaka, H., Iwasawa, H., Wang, D., Toyoda, N., Aoki, T., Yudasaka, I., Matsuki, Y., Shimoda, T. and Furusawa, M. (2007) Spin-on N-Type Silicon Films Using Phosphorous-Doped Polysilanes. Japanese Journal of Applied Physics, 46, L886-L888. https://doi.org/10.1143/JJAP.46.L886

[18] De Wolf, I. (2003) Raman Spectroscopy: About Chips and Stress. Spectroscopy Europe, 15, 6-13.

[19] Yoshino, K., Hosoda, K., Fujii, A. and Ishikawa, M. (1997) Optical Properties and EL Characteristics of Poly[(Disilanylene)Oligophenylenes]. Japanese Journal of Applied Physics, 36, L368-L371.https://doi.org/10.1143/jjap.36.1368 
[20] Oku, T., Takeda, A., Nagata, A., Kidowaki, H., Kumada, K., Fujimoto, K., Suzuki, A., Akiyama, T., Yamasaki, Y. and Ōsawa E. (2013) Microstructures and Photovoltaic Properties of $\mathrm{C}_{60}$-Based Solar Cells with Copper Oxides, CuInS 2 , Phthalocyanines, Porphyrin, PVK, Nanodiamond, Germanium and Exciton-Diffusion Blocking Layers. Materials Technology, 28, 21-39.

https://doi.org/10.1179/1753555712Y.0000000042

[21] Jin, Y.K., Sun, H.K., Hyun, H.L., Kwanghee, L., Wanli, M., Xiong, G. and Alan, J.H. (2006) New Architecture for High-Efficiency Polymer Photovoltaic Cells Using Solution-Based Titanium Oxide as an Optical Spacer. Advanced Materials, 18, 572576. https://doi.org/10.1002/adma.200501825

[22] Oku T., Ohishi Y., Suzuki A. and Miyazawa Y. (2016) Effects of Cl Addition to Sb-Doped Perovskite-Type $\mathrm{CH}_{3} \mathrm{NH}_{3} \mathrm{PbI}_{3}$ Photovoltaic Devices. Metals, 6, 147. https://doi.org/10.3390/met6070147

[23] Shirahata, Y., Yamomoto, Y., Suzuki, A., Oku, T., Fukunishi, S. and Kohno, K. (2017) Effects of Polysilane-Doped Spiro-OMeTAD Hole Transport Layers on Photovoltaic Properties. Physica Status Solidi A, in press.

https://doi.org/10.1002/pssa.201600591

\section{Scientific Research Publishing}

Submit or recommend next manuscript to SCIRP and we will provide best service for you:

Accepting pre-submission inquiries through Email, Facebook, LinkedIn, Twitter, etc. A wide selection of journals (inclusive of 9 subjects, more than 200 journals)

Providing 24-hour high-quality service

User-friendly online submission system

Fair and swift peer-review system

Efficient typesetting and proofreading procedure

Display of the result of downloads and visits, as well as the number of cited articles

Maximum dissemination of your research work

Submit your manuscript at: http://papersubmission.scirp.org/

Or contact gsc@scirp.org 